\title{
Development of Control Design Scheme Using Nonlinear Analysis
}

\author{
__PSS Parameter Design Effective for Suppression of Oscillatory Instability__ \\ Hiroyuki Amano Member (CRIEPI, h-amano@criepi.denken.or.jp) \\ Toshio Inoue Member (CRIEPI, inotoshi@criepi.denken.or.jp)
}

Keywords: power system, rotor angle stability, control design scheme, nonlinearity, oscillatory instability, normal form theory

Phenomena in power systems tend to exhibit higher nonlinearity, because efficient operation accompanies severer power transfer. In such cases, there might exist some limitation to the use of conventional linear control design scheme due to the nonlinearity.

As for consideration to the nonlinearity, we have developed a nonlinear analysis method based on normal form theory. In this paper, we develop a new control design scheme based on the nonlinear analysis method.

Figure 1 shows the flow chart of the developed method. The developed method is effective in a case when oscillatory instability occurs. In the developed method, the parameters of control devices are adjusted so as to enlarge the stability limit against the oscillatory instability, unless each eigenvalue exceed its allowable threshold.

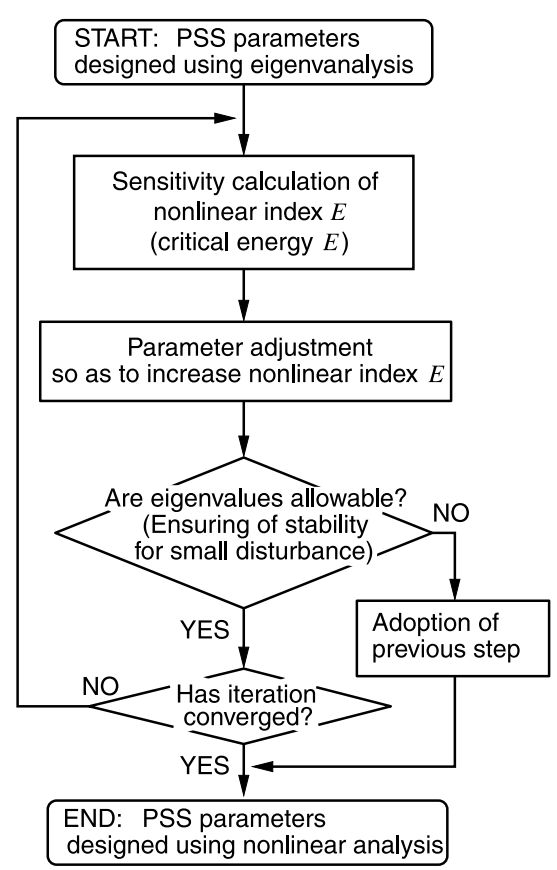

Fig. 1. Flow chart of developed method
We verify the effectiveness of the new control design scheme in the IEEJ 10-machine System Model by applying to PSS (Power System Stabilizer). Figure 2 shows a time-domain simulation results for a large disturbance when we apply the linear design or the developed nonlinear design. All eigenvalues are stable in both case. However, in the linear design case, the oscillatory instability occurs due to the nonlinearity as shown in Fig. 2(a). In contrast, in the developed nonlinear design case, the oscillation can be attenuated as shown in Fig. 2(b). We examine the power transfer limit and show that it increases by a few percent.

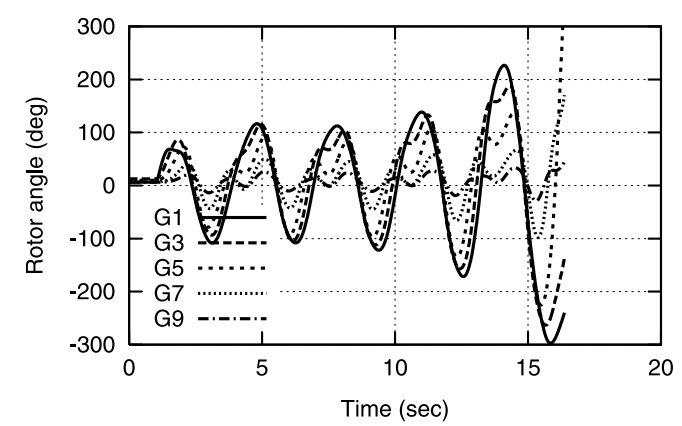

(a) Linear design case

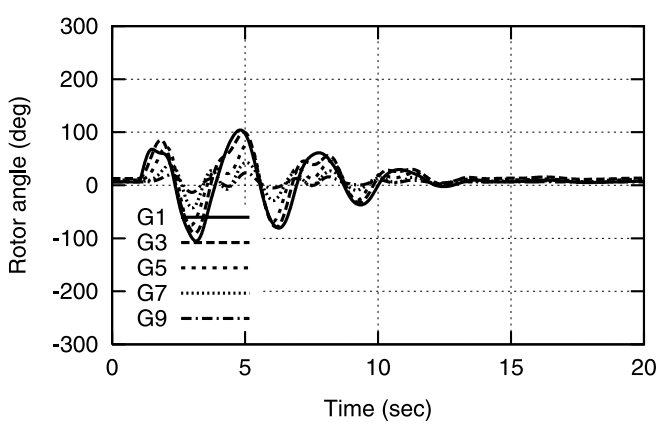

(b) Developed nonlinear design case

Fig. 2. Time-domain simulation results for large disturbance 


\title{
非線形解析理論を用いた制御系設計手法の開発 \\ 一振動発散の抑制に有効な PSS 定数設定法——
}

\author{
正 員 天野 博之* 正 員 井上 俊雄* \\ Development of Control Design Scheme Using Nonlinear Analysis \\ _-PSS Parameter Design Effective for Suppression of Oscillatory Instability_— \\ Hiroyuki Amano*, Member, Toshio Inoue*, Member
}

\begin{abstract}
Phenomena in power systems tend to exhibit higher nonlinearity, because efficient operation accompanies severer power transfer. In such cases, there might exist some limitation to the use of conventional linear control design scheme due to the nonlinearity. As for consideration to the nonlinearity, we have developed a nonlinear analysis method based on normal form theory. In this paper, we develop a new control design scheme based on the nonlinear analysis method.

The developed method is effective in a case when oscillatory instability occurs. In the developed method, the parameters of control devices are adjusted so as to enlarge the stability limit against the oscillatory instability, unless each eigenvalue exceed its allowable threshold. We verify the effectiveness of the developed method in the IEEJ 10-machine System Model by applying to PSS (Power System Stabilizer). We show that the power transfer limit increases by a few percent.
\end{abstract}

キーワード : 電力系統, 同期安定度, 制御系設計, 非線形性, 振動発散, 標準形理論

Keywords: power system, rotor angle stability, control design scheme, nonlinearity, oscillatory instability, normal form theory

\section{1. はじめに}

電力系統は様々な非線形の特性を有するが, 従来の同期 安定度の向上を目的とした制御系の設計では，線形解析が 多く用いられてきた。これに関し著者らは，同期安定度に おける振動発散現象に対して非線形性を考慮できる安定性 解析手法を開発してきた(1)(2)。この手法を制御系の設計に 適用することができれば，振動発散に対する安定性を更に 向上できる可能性があり, 限界送電電力の増加につながる と考えられる。

本論文では，既開発の安定性解析手法を基に振動発散の 抑制に有効な制御系設計手法を開発し，モデル系統におい て PSS (Power System Stabilizer) の定数設定に適用し，そ の有効性を検証した結果について述べる。

今後の電力系統では，コスト低減のための既存設備の最 大限の活用, 自由化の進展等により, 更に重潮流化が進むこ とが予想され，PSSによる系統の安定化は益々重要となる と考えられる。このため新しいPSS の方式として, 無効電

\footnotetext{
* (財) 電力中央研究所

干 201-8511 狛江市岩戸北 2-11-1

Central Research Institute of Electric Power Industry

2-11-1, Iwadokita Komae 201-8511
}

力や位相角偏差などを入力信号に加える方式 (3)(4) や遠端情 報を入力する方式 ${ }^{(5)}$ などが開発され, PSS の設計手法（制 御定数の設定方法) についても固有值感度を用いた方法 ${ }^{(5)}$ や遺伝的アルゴリズムを用いた方法 ${ }^{(6)}$ など多くの方法が開 発されている。

しかし，そのほとんどは線形解析（固有值解析やボード 線図）をベースとした設計手法であるため，小外乱に対す る減衰率（ダンピング）に関しては適切な設計を行うこと が可能であるが, 非線形性が影響する大外乱に対しての安 定性に関しては，必ずしも望ましい特性が得られるとは限 らない。したがって, 最終的にはシミュレーション解析に よる非線形性の影響の確認が必要であり (7), 場合によって は試行錯誤的な定数の調整が必要となる。

これに対して本研究で開発した設計手法は, 系統の非線 形性を解析的に直接考慮するという新たなアプローチで大 外乱に対する安定性の向上を図るものであり, 線形解析に よって得られた設計定数をスタートとして定数を更に調整 するものである。すなわち, 線形解析に基づいた設計にお ける最終的なステップ (非線形性の影響の確認, 場合によっ ては必要となる定数の調整) の負担軽減, および, 非線形 性を考慮した更なる安定性の向上を目指したものである。 開発した手法は非線形性によって振動発散が生じる場合 
に有効であり，大外乱に対する振動の安定性を評価する指 標を用いて，これが向上するように定数の調整を行うこと によって, 限界送電電力の増加を図る。但し，小外乱を対 象に最適化を行う固有值解析に基づく手法と比較すると, 開発手法では小外乱に対しての最適性は失われることにな る。したがって，小外乱に対するダンピングを許容範囲内 に留めつつ, 定数の調整を行うことを前提としている。

本論文の構成は以下のと扔りである。2 章では開発した 非線形性を考慮した制御系設計手法について説明し，3章

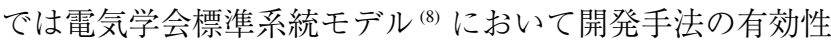
を検証する。最後に 4 章で得られた結果についてまとめる。

\section{2. 非線形性を考慮した制御系設計手法の開発}

既開発の非線形性を考慮した安定性解析手法を基に, 非線 形性を考慮して制御系定数の調整を行う新たな手法を開発 した。本章では，開発した制御系設計手法について述べる。

$\langle\mathbf{2} \cdot \mathbf{1}\rangle$ 非線形性による振動発散 電力系統は，いわゆ る $P-\delta$ カーブや制御系のリミッ夕等の種々の非線形性を持 ち, 次数で言えば低次から高次までの非線形性を持つ。す なわち, 系統の運転点で系統の動特性を表す微分方程式を テイラー展開すると, 線形項に加えて高次の項 (非線形性) までを含むことになる。

ここで, 系統の非線形性が動摇の減衰率に及ぼす影響に ついて, 外乱の大きさ（動摇の大きさ）と減衰率の関係をイ メージした図 1 を用いて説明する(1)(2)。線形解析である固 有值解析によって得られる固有值の実部は, 線形領域での 減衰率，すなわち小外乱に対する動摇の減衰率に対応する。 一方，外乱が大きくなり非線形性の影響が増大すると，減 衰率は固有值とは異なった值となる（動摇周波数について も同様である)。したがって図 1 の実線のような特性を持 つ場合には，小外乱に対しては安定であったとしても，外 乱が大きくなるにつれて減衰率が悪化し, 外乱が安定限界 となる振幅 (critical amplitude) を越えると動摇が発散して しまう。開発手法が有効となるのは，このような系統の非 線形性による振動発散が生じて安定領域が制限される場合 である。

時間領域での非線形性による振動発散の波形のイメージ を図 2 に示す。小外乱に対しては点線のように安定である が，外乱が大きくなると実線のように動摇が発散する場合 である。ここで，安定な場合と不安定な場合の境界に対応 する安定限界の場合（振幅が critical amplitude となる場合） には，一点鎖線のように動摇は減衰も発散もせず周期的に 繰り返され周期軌道となる。

一機無限大母線系統では, 非線形性による振動発散が生 ずるのは稀であると考えられるが，多機系統では広域モー ド間の相互作用などの非線形性によって振動発散が生ずる 可能性がある(2)(9)(10)†。前述したように電力系統には種々の

†後述する電気学会標準系統モデルでは非線形性による振動発散が 生じる場合が少なくない。

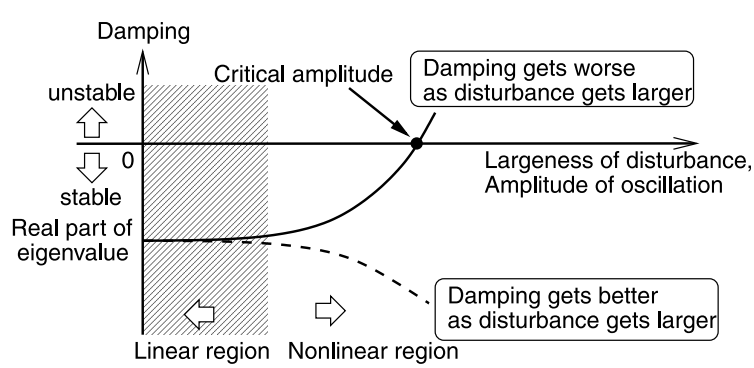

図 1 減衰率への非線形性の影響

Fig. 1. Effect of nonlinearity on damping.

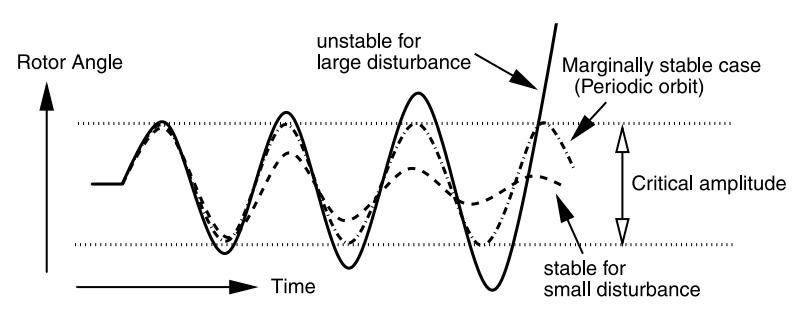

図 2 非線形性による振動発散

Fig. 2. Oscillatory instability due to nonlinearity.

次数の非線形性があるが，多機系統での広域モード間の相 互作用による振動発散に扔いては，比較的低次（2 次ある いは3 次）の非線形性の影響が大きく茾，これら比較的低 次の項のみを考慮することによって, 基本的な特性を解析 できることが知られている(2)(9)(10)。

\section{〈2・2〉 既開発の非線形性を考慮した安定性解析手法}

既開発の安定性解析手法は, 標準形理論 (normal form theory) (12)(13) と呼ばれる非線形解析理論を応用したもので ある(1)(2)。本節では，この手法に関して簡単に説明する。

非線形性による振動発散が生じる場合を考える。固有べ クトルを利用して安定限界の場合に対応する周期軌道の一 周期分の波形 (図 3) を各動摇モードに分解する ${ }^{(1)}$ と, 図 4 のようになる。図4のように, 動摇モードの中には, 振動 発散に大きく関与する（振幅が大きい）モードとほとんど 関与しない（振幅が小さい）モードがある讯。また，いず れのモードについても, 動摇周波数は周期軌道の基本周波 数の $n$ 倍 ( $n$ は整数) となる。なお, 各モードの固有值虚部 （振幅が小さい場合の周波数）は整数比ではなくても，周期 軌道においては非線形性の影響により各モードの周波数は 整数比となる（同期する）。逆に言えば，周期軌道における 各モードの振幅㧍よび位相は, 減衰率が零かつ周波数が整 数比となるという条件によって定まる计†。

既開発の安定性解析手法は，この条件を基に周期軌道を 求める手法である。具体的には, 振動発散に大きく関与す る各動摇モードに関して, 周期軌道に抢ける振幅 (critical

\footnotetext{
†なお，過渡第一波に関しては，より高次の非線形性の影響が大き いと考えられる。

计多機系では振動発散に関与するモードは複数存在することが多い。

柿†図 1 に関して, 動摇モード間の相互作用が強い場合は, 正確に 言うと減衰率は動摇の振幅だけでなく位相にも依存する(2)。
} 


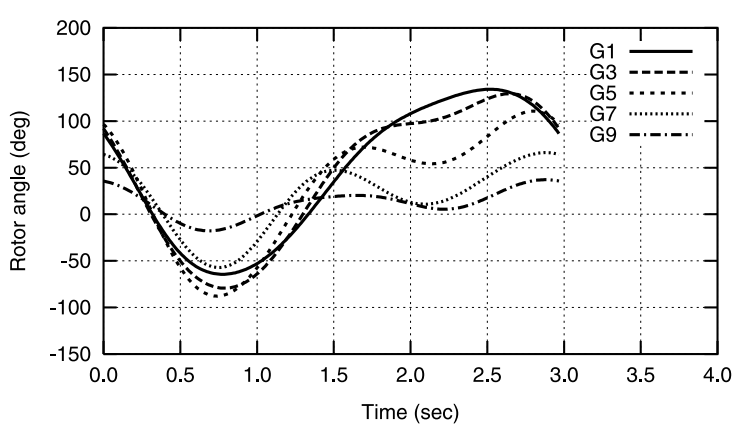

図 3 周期軌道における内部相差角の例

Fig. 3. Example of rotor angle on periodic orbit.

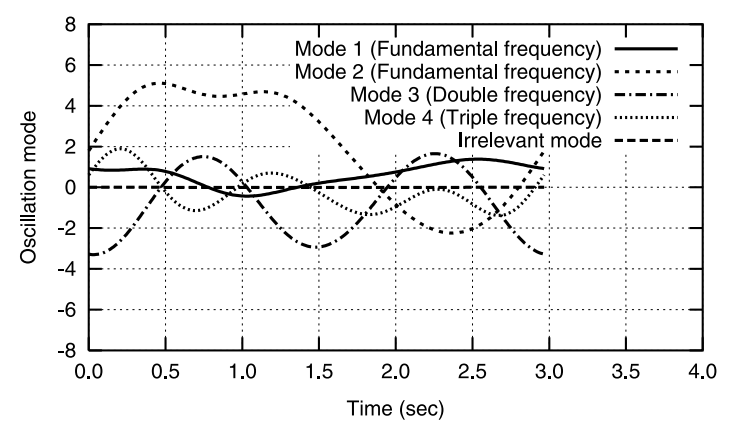

図 4 周期軌道における各動摇モードの例

Fig. 4. Example of oscillation mode on periodic orbit.

amplitude に対応）と位相の近似值を求めることができる。

なお，既開発の安定性解析手法において考慮する非線形 性は 3 次までであるため, 4 次以上の非線形性あるいは制 御系のリミッ夕の影響は考慮できない。

$\langle 2 \cdot 3\rangle$ 非線形性を考慮した制御系設計手法既開発 の非線形性を考慮した安定性解析手法を基に，非線形性を 考慮して振動発散に関する安定性を高める新しい制御系設 計手法を開発した。

$\langle\mathbf{2} \cdot \mathbf{3} \cdot \mathbf{1}\rangle$ 開発手法の概要 開発手法の基本的な考え 方は，以下の 2 つである（図 5)。

-限界送電電力の増加を目的に，大外乱に対する安定性 が向上するような設計を行う。具体的には，安定限界 の場合に対応する周期軌道の振幅 (critical amplitude) は振動発散に関する安定領域の広さに概ね対応すると 考えられることから，これを大きくすることによって 大外乱に対する安定性の向上を図る。

- 小外乱を対象に最適化を行う固有值解析に基づく手法 と比較すると, 小外乱に対する減衰率 (固有值実部) の 最適性が失われるため，これを許容範囲内に留める。 開発した制御系設計手法のフロー図を図 6 に示す。開発 手法では, 固有值解析を用いて調整した制御系定数をスター トとし，安定領域の大きさを評価する指標 $E$ を用いて，こ れが大きくなる方向に定数を調整する。但し，固有值実部 （小外乱に対する減衰率に相当）に対しては，適切なしきい 值を定め，これを越えない範囲内で定数の調整を行う。最 終的には，制御定数および指標の变化幅が小さくなった時

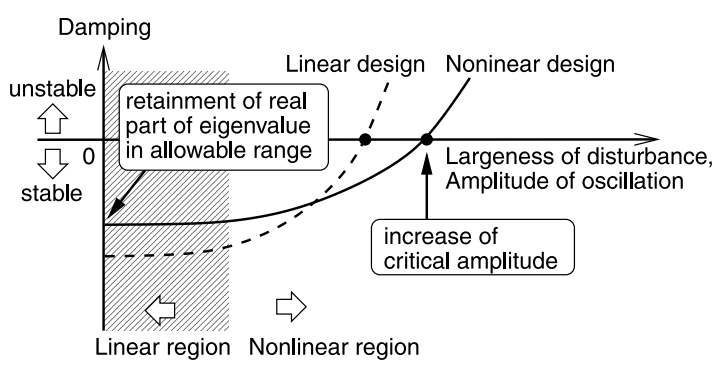

図 5 開発手法の基本的な考え方

Fig. 5. Basic concept of developed method.

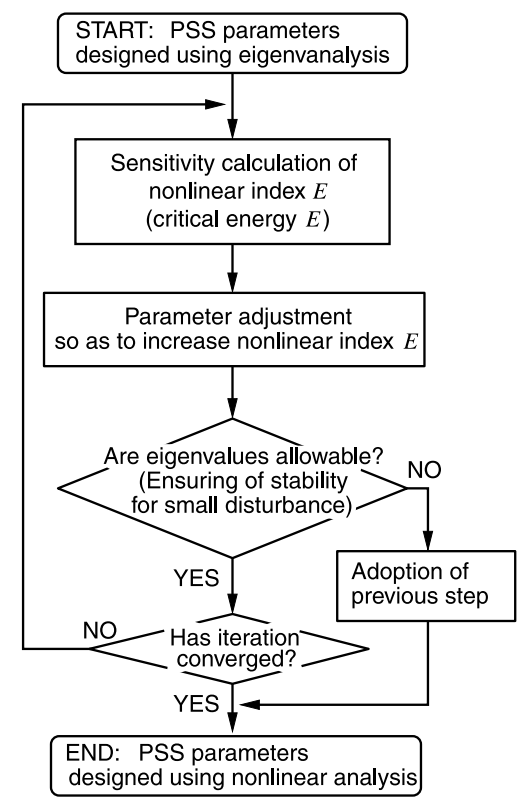

困 6 開発手法のフロー困

Fig. 6. Flow chart of developed method.

点, あるいは, 既開発の安定性解析手法によって周期軌道 が算出できなくなった（安定領域が十分広くなったと判定 された）時点で定数の調整を終了し，指標が最大となる定 数を採用することとする。

なお，開発手法は既開発の安定性解析手法を基にしてい るため，4 次以上の非線形性あるいは制御系のリミッ夕の 影響は考慮できない。

以下では，特に安定領域の大きさを評価する指標 $E ， お ~$ よびその感度を基にした定数調整について説明する。

$\langle\mathbf{2} \cdot \mathbf{3} \cdot \mathbf{2}\rangle$ 安定限界エネルギーの導入 既開発の非線 形性を考慮した安定性解析手法によって，安定限界に対応 する周期軌道（周期軌道における各モードの振幅と位相）が 得られる。しかし, 振動発散に関する安定領域を考慮して 制御系の設計を行うにあたっては，何らかの形でこれらの 各モードの振幅と位相を一つの指標にまとめる必要がある。

そこで，以下に説明する振動発散に関する安定限界エネ ルギーという概念を導入し，これを振動発散に関する安定 領域の大きさを評価する指標 $E$ として用いることとした。 まず，既開発の安定性解析手法によって得られる周期軌 
道に扔ける各モードの振幅 $R_{i}$ と位相 $\Theta_{i}$ を用いて, 周期軌 道を表現すると次のようになる。

$$
x(t)=\sum_{i \leq N} a_{i} R_{i} \exp \left\{\mathrm{j}\left(n_{i} \Omega t+\Theta_{i}\right)\right\} .
$$

なお， $x(t)$ は状態変数, $N$ はモードの総数, $a_{i}$ はモード $i$ の 固有べクトル， $\Omega$ は周期軌道の基本周波数 $(2 \pi /$ /周期 $), n_{i}$ はモード $i$ の周波数の $\Omega$ に対する比（整数）である。また， 振動発散に関与しないモードに関しては, 振幅 $R_{i}$ は零で ある。

(1) 式は, $n_{i}=k(k=1,2,3)$ であるモードの集合を $N_{k}$ と 表すと次のように書ける。なお, 既開発の安定性解析手法 では 3 次までの非線形性を考慮していることに対応して 3 倍周波数まで考慮する。

$$
\begin{aligned}
x(t)= & \left(\sum_{i \in N_{1}} a_{i} R_{i} \exp \left(\mathrm{j}_{i}\right)\right) \exp (\mathrm{j} \Omega t) \\
& +\left(\sum_{i \in N_{2}} a_{i} R_{i} \exp \left(\mathrm{j} \Theta_{i}\right)\right) \exp (\mathrm{j} 2 \Omega t) \\
& +\left(\sum_{i \in N_{3}} a_{i} R_{i} \exp \left(\mathrm{j} \Theta_{i}\right)\right) \exp (\mathrm{j} 3 \Omega t) \\
= & A_{1} \exp (\mathrm{j} \Omega t)+A_{2} \exp (\mathrm{j} 2 \Omega t)+A_{3} \exp (\mathrm{j} 3 \Omega t)
\end{aligned}
$$

これは，周期軌道を基本周波数， 2 倍周波数， 3 倍周波数の 各成分で表現したことに対応する。

ここで周期軌道全体に対応するエネルギーを各周波数成 分のエネルギーの和として捉えることとし，各周波数成分 のエネルギーを以下のように定義する。

まず，それぞれの $n$ 倍周波数成分について，

$$
\begin{aligned}
x_{n}(t) & =A_{n} \exp (\mathrm{j} n \Omega t) \\
& =\left(\operatorname{Re}\left[A_{n}\right]+\mathrm{j} \operatorname{Im}\left[A_{n}\right]\right)\{\cos (n \Omega t)+\mathrm{j} \sin (n \Omega t)\}
\end{aligned}
$$

と表現し，次式の運動エネルギー $E_{n}^{\text {kinetic }}(t)$

$$
E_{n}^{\mathrm{kinetic}}(t)=\sum_{j \leq M} \frac{1}{2} m_{j}\left(\Delta \omega_{j}^{\mathrm{COA}}(t)\right)^{2}
$$

に着目する。ここで, $M$ は発電機総数, $m_{j}$ は発電機 $j$ の慣 性, $\Delta \omega_{j}^{\mathrm{COA}}(t)$ は慣性中心を基準とした発電機 $j$ の角速度偏 差である。なお，(3)式より $\Delta \omega_{j}^{\mathrm{COA}}(t)$ は三角関数を用いて 表現可能である。

この運動エネルギー $E_{n}^{\mathrm{kinetic}}(t)$ が周期軌道においてとり得 る最大值を，各 $n$ 倍周波数成分のエネルギー $E_{n}$ と見なす こととする 。 $E_{n}^{\mathrm{kinetic}}(t)$ は三角関数の合成で表現されるた め，容易に最大值を計算できる。すなわち，各 $n$ 倍周波数 成分のエネルギー $E_{n}$ は次式のように定義される。

\footnotetext{
厳密にはポテンシャルエネルギー等も関係すると考えられる ${ }^{(11)}$ が, 簡単には表現できないため，運動エネルギーのみを考慮することとし た。
}

$$
E_{n}=\max _{t} E_{n}^{\mathrm{kinetic}}(t)
$$

最終的に，周期軌道全体に対応するエネルギーを，次式 のように各周波数成分のエネルギー $E_{n}$ の和で定義し，振 動発散に関する安定限界エネルギー $E$ と呼ぶことにする。

$$
E=E_{1}+E_{2}+E_{3}
$$

このように定義した振動発散に関する安定限界エネルギー $E$ を大きくすることによって, 振動発散に関する安定領域が 拡大され，大外乱に対する安定性が向上すると考元られる。

$\langle\mathbf{2} \cdot \mathbf{3} \cdot \mathbf{3}\rangle$ 制御系定数の変化に対する感度の利用 振 動発散に関する安定限界エネルギー $E$ を大きくするように 制御系定数 $P^{\dagger \dagger}$ を調整するため, $P$ の変化に対する $E$ の感 度 $\partial E / \partial P$ を利用して次式のように定数の調整を行うこと とした。

$$
P^{(k+1)}=P^{(k)}+\left.\alpha \frac{\partial E}{\partial P}\right|_{P=P^{(k)}}
$$

ここで， $P^{(k)}$ は $k$ 回目の調整ステップでの定数である。

なお, 定数調整の度に $\partial E / \partial P$ を厳密に計算すると, 計算 量が多大となるという問題がある。そこで以下のように近 似的な感度を算出して $E$ が大きくなる方向に少しずつ定数 を調整することとした。

- 2 次と 3 次の非線形項については計算量が多大となる ことから，これらについては一定であると見なして近 似的な感度を計算する。

- $\alpha$ は $0.01 \sim 0.10$ 程度, 定数の最大変化幅は $0.01 \sim 0.02$ 程度とし，少しずつ定数を調整する。

・上記のように定数を調整しても $E$ が低下するような場 合姶は，反対方向に定数を調整する。

\section{3. 開発した制御系設計手法の有効性の検証}

本章では，電気学会標準系統モデルにおいて開発手法を PSS の定数設定に適用し, シミュレーション解析 (timedomain simulation）等から線形解析を用いた設計との比較 を行い, 開発手法の有効性を検証する。

なお，前章で述べたように開発手法では制御系リミッ夕 の影響は考慮できないが，シミュレーション解析はリミッ 夕を考慮して行い，その影響を含めて開発手法の有効性を 検証する。

$\langle\mathbf{3} \cdot 1\rangle$ 電気学会標準系統モデル 解析の対象とした 系統モデルは, わが国の西地域, 東地域の電力系統を模擬 したWEST10 機系統モデルと EAST10 機系統モデルであ る。これらのモデルでは, 実系統の系統構成を模擬し, 実 系統と同程度の長周期動摇が発生するようになっている。 以下では, 本モデルの概要求よびオリジナルのモデルから の変更点について述べる。潮流条件, インピーダンスマッ プなどの詳細については文献(8)を参照されたい。

\footnotetext{
†複数の制御系定数をまとめてベクトル表記したものを $P$ とする。 计感度 $\partial E / \partial P$ を近似的に計算しているため, 厳密な感度との差が 大きい場合には (7) 式に従って定数を調整しても $E$ が低下する場合が ある。
} 
$\langle\mathbf{3 \cdot 1 \cdot 1 \rangle}$ 潮流条件本研究では昼間断面を対象とし た。限界送電電力を求める際は, 発電機の出力を変更した。

$\langle\mathbf{3 \cdot 1 \cdot 2 \rangle}$ 発電機モデル 発電機は $d, q$ 軸に各 1 個の 制動回路を考慮したモデルである。

〈3.1.3〉 励磁系モデル AVR は基本的には回転形励 磁機用モデルである。但し, 開発した制御系設計手法を適 用する発電機については, 図 7 の $\Delta \mathrm{P}$ 形 PSS 付サイリス夕 励磁系モデルに変更した。

PSS の定数に関しては, リセット回路時定数は長周期動 摇に対しても効果を期待できるよう 5.0 秒とし, 最終段の 一次遅れ時定数は 0.02 秒とし, 他については調整対象と した。

なお，AVR，PSS のリミッ夕は同期安定度（特に過渡第 一波）に大きく影響するため，シミュレーション解析にお いてはこれらのリミッタを考慮した（PSS の出力リミッタ は $\pm 0.10 \mathrm{pu}$ としたや)。

$\langle\mathbf{3 \cdot 1 \cdot 4 \rangle}$ 調速機系モデル 調速機系は火力・原子力 機用と水力機用のモデルが使用されている。なお，調速機 系のリミッ夕は同期安定度にあまり影響しないため, 簡単 のため無視することとした。

$\langle\mathbf{3 \cdot 1 \cdot 5 \rangle}$ 負荷特性 簡単のため, 負荷は定インピー ダンスとし, 周波数特性はなしとした。

$\langle\mathbf{3} \cdot \mathbf{2}\rangle$ 開発手法の有効性の検証 下記の発電機につ いて, 開発手法を用いて PSS 定数の調整を行った。

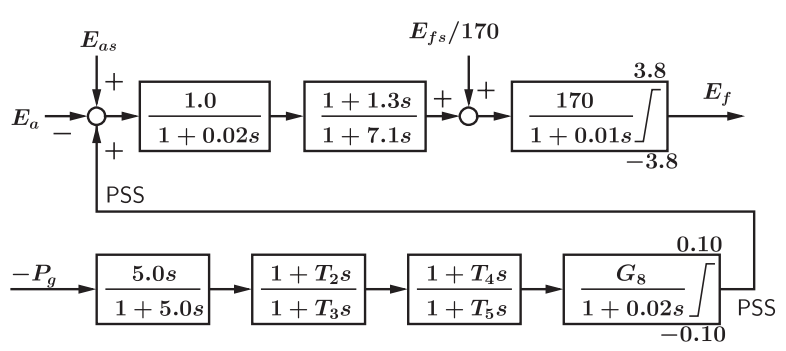

図 $7 \Delta \mathrm{P}$ 形 PSS 付サイリス夕励磁系モデル Fig. 7. Thyristor-type exciter model equipped with $\Delta \mathrm{P}$ type PSS.
・WEST10 機系統モデル：G1, G10（それぞれにPSSを 設置した場合を検討)

- EAST10 機系統モデル：G10

調整の対象としたPSS 定数は，2段の進み遅れ時定数 $T_{2}$, $T_{3}, T_{4}, T_{5}$ とゲイン $G_{8}$ である(図 7)。なお, ゲイン $G_{8}$ に関しては，ゲインが上がり過ぎないように計調整の上限 を 1.0 とした。

以下では, WEST10 機系統 (図 8) の G1 にPSS を設置し て開発手法を適用した場合を例にとり，具体的に説明する。

$\langle\mathbf{3 \cdot 2 \cdot 1 \rangle}$ 固有值を用いた設計 まず，固有值を用い て定数を調整した結果, 下記の定数が得られた（図 9）。

$$
\frac{5 s}{1+5 s} \cdot \frac{1+0.5163 s}{1+0.3696 s} \cdot \frac{1+0.0580 s}{1+0.3665 s} \cdot \frac{1.000}{1+0.02 s}
$$

ここでは, 次式の指標 $F^{(5)}$ が小さくなるように定数の調 整を行った。

$$
F=\sum_{i} \exp \left(k_{f} \cdot \operatorname{Re}\left[\lambda_{i}\right]\right), \quad k_{f}=10
$$

考慮する固有值については, 減衰比 $\left(-\operatorname{Re}\left[\lambda_{i}\right] /\left|\lambda_{i}\right|\right)$ が 0.2 程度以下のものを選んだ。なお, 本研究では $\mathrm{QR}$ 法に よって全ての固有值を算出した。また, 定数の初期值は $T_{2}=T_{4}=0.2, T_{3}=T_{5}=0.8, G_{8}=0.5$ とした计。

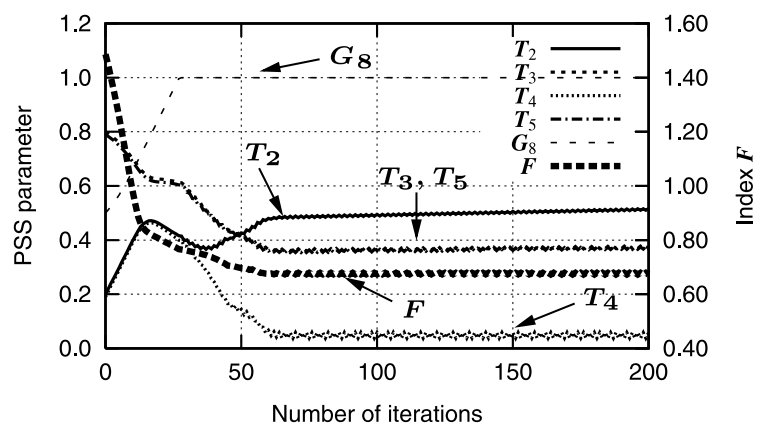

図 9 線形解析を用いた設計過程での PSS 定数および指標 $F$ の変化

Fig.9. Variation of PSS parameters and index $F$ through linear design.

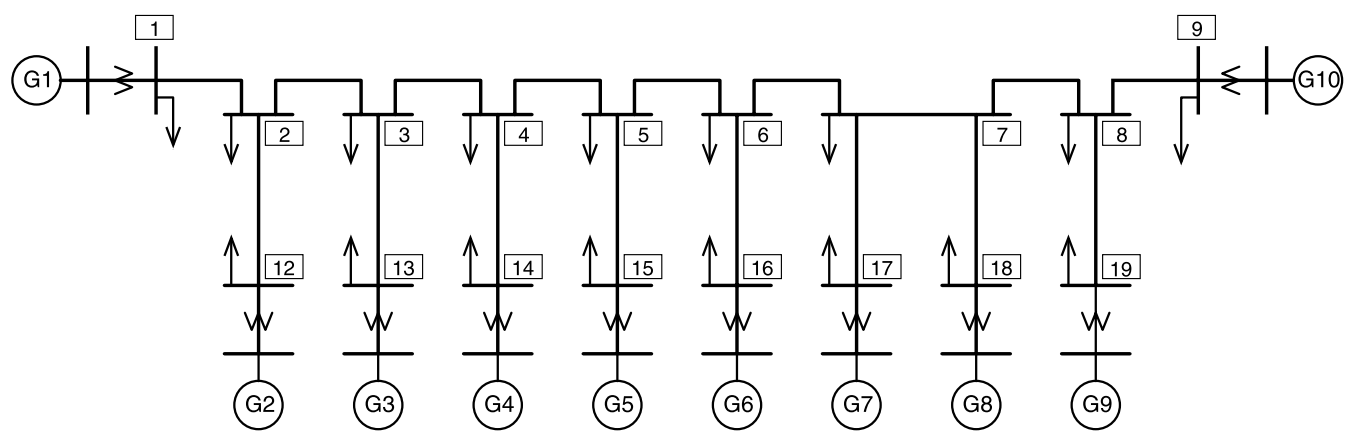

図 8 電気学会 WEST10 機系統モデル

Fig. 8. IEEJ West 10-machine system model.

\footnotetext{
†リミッタを $\pm 0.05 \mathrm{pu}$ とした場合の影響をく3・2・6〉項で検討してい る。
}

\begin{tabular}{l}
\hline$\dagger$ 一般的に，ゲインを上げ過ぎるとPSS のリミッタに張りつき易い \\
状況となり，好ましい結果が得られないことが多い。 \\
†† 折れ点周波数を約 $0.2 \mathrm{~Hz}$ と約 $0.8 \mathrm{~Hz}$ に設定したことに相当する。
\end{tabular} 


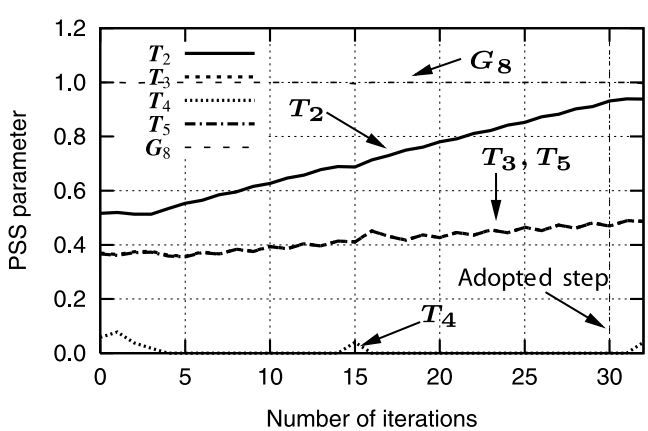

(a) Variation of PSS parameters.

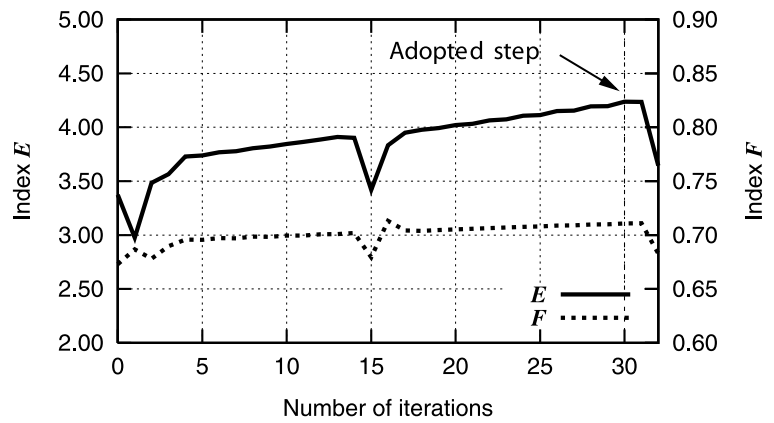

(b) Variation of indexes $F$ and $E$.

困 10 非線形解析を用いた設計過程での

PSS 定数および指標 $F, E$ の变化

Fig. 10. Variation of PSS parameters and indexes $F$ and $E$ through developed nonlinear design.

なお，実際に固有值解析に基ついて設計を行う場合には， 最終的にシミュレーション解析を行いながら必要に応じて 定数を更に調整することになる。しかし本論文では，開発 手法により非線形性を考慮して更に調整を行った場合，ど の程度の効果があるのかを調べるという観点から，固有値 解析により直接得られた定数との比較を行う。

$\langle\mathbf{3 \cdot 2 \cdot 2}\rangle$ 開発手法による設計 次に，固有值を用い て設定した定数をスタートとして, 開発手法によって振動 発散に関する安定限界エネルギー $E$ が大きくなるように定 数の調整を行った結果を図 10 に示す。

固有值実部の許容範囲に関しては, 固有值を用いて設計し た場合での最も減衰の悪い固有值の実部が約 -0.09 であっ たため,ここでは -0.05 以下とした。 33 回目の調整におい て既開発の安定性解析手法により周期軌道が算出できなく なった（安定領域が十分広くなったと判定された）ため，安 定限界エネルギー $E$ が最大となった 30 回目の下記の定数 を採用した。

$$
\frac{5 s}{1+5 s} \cdot \frac{1+0.9309 s}{1+0.4698 s} \cdot \frac{1+0.0000 s}{1+0.4692 s} \cdot \frac{1.000}{1+0.02 s}
$$

時折 $(1,15,32$ 回目) 安定限界エネルギー $E$ が減少し ている箇所がある゙が，基本的に安定限界エネルギー $E$ が大 きくなるように定数が調整されており, 前述の $\langle 2 \cdot 3 \cdot 3\rangle$ 項 で示した定数調整法は有効であると考えられる。

$\dagger\langle 2 \cdot 3 \cdot 3\rangle$ 項で述べた, 厳密な感度 $\partial E / \partial P$ と近似的に求めた感度と の差が大きい場合に対応すると考えられる。

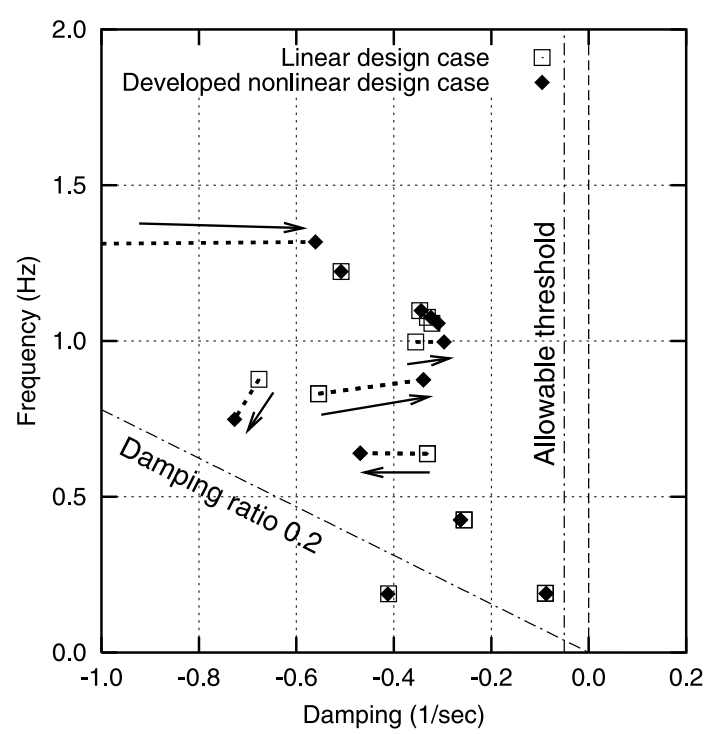

図 11 固有值の変化

Fig. 11. Variation of eigenvalues.

なお，固有值に関する指標 $F$ は若干悪化している（值が 大きくなっている) が，いずれの固有值についても実部が しきい值 -0.05 を越えることはなかった。参考として, 開 発手法による定数調整の前後での固有值（減衰比 0.2 程度 以上）の動きを図 11 に示す。

$\langle\mathbf{3} \cdot \mathbf{2} \cdot \mathbf{3}\rangle$ 小外乱に対する安定性 固有值に関する指 標 $F$ が若干悪化することに留意して, 小外乱に対する安定 性の確認を行った。ここでは, 小外乱として発電機至近端 の $10 \mathrm{msec} の$ 三相地絡故障（但し, 故障除去後は元の系統 に戻す）を想定した。小外乱に対して，固有值を用いて設 計した場合と開発手法を用いて設計した場合のシミュレー ション結果を図 12 に示す。なお，位相角の基準は G10 と している。

指標 $F$ の悪化に対応して, 小外乱に対する安定性は若干 低下する（図 11 に対応して, 特に G1 に関する約 $1.3 \mathrm{~Hz}$ の ローカルモードの安定性が低下する）が, 許容できる範囲 にあると考えられる。

$\langle\mathbf{3 \cdot 2 \cdot 4 \rangle}$ 安定限界となる振幅開発手法を適用する 前後での安定限界となる波形 (周期軌道) を繰り返し計算 によって求めた。具体的には, 動摇の振幅（外乱の大きさ に相当）を変えてゆき，周期軌道となるような波形を求め た。その結果を図 13 に示す。

図 13 より, 開発手法によって周期軌道の振幅 (Crtical Amplitude) が大きくなっておりけ, 図 5 に示したような設 計が実現できていることが確認できる。

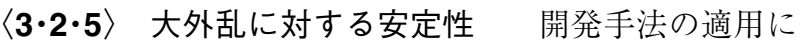
よる大外乱に対する安定性の向上効果を調べた。ここでは, 発電機至近端での $70 \mathrm{msec} の 三$ 相地絡故障 (但し, 故障除去 後は元の系統に戻す) を想定し, G1 の発電機出力を $0.05 \mathrm{pu}$

\footnotetext{
†ち与えた外乱に関しては，開発手法の場合の方が大きい。
} 

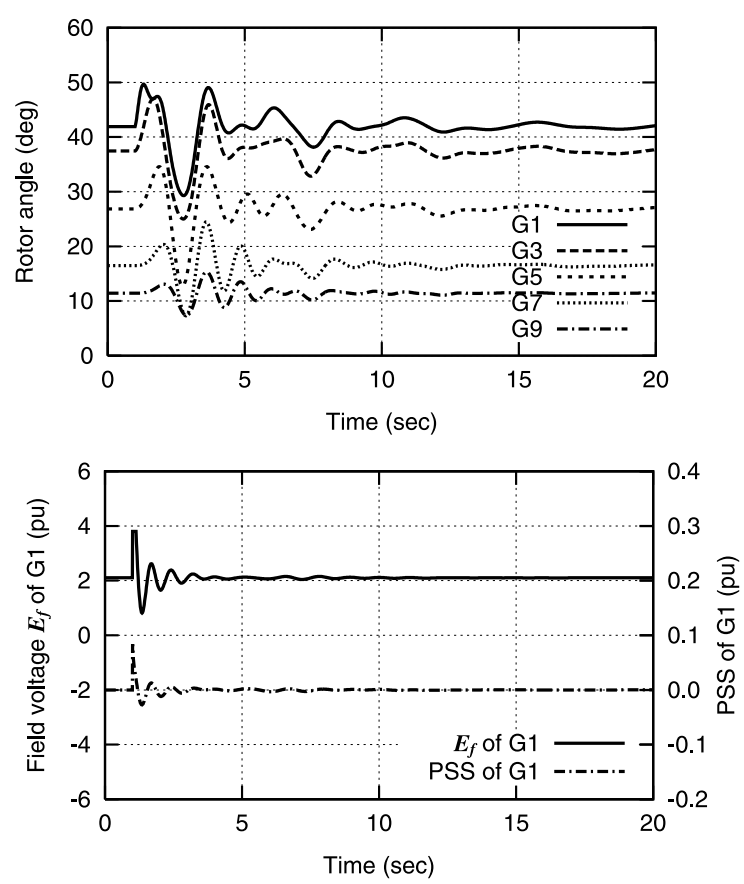

(a) Linear design case
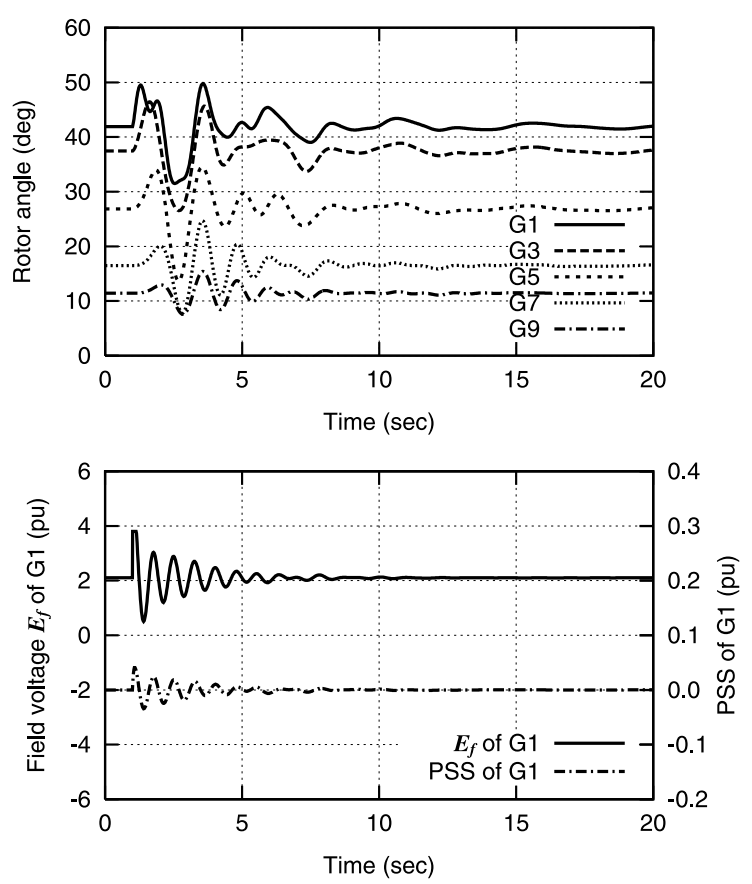

(b) Developed nonlinear design case

図 12 小外乱に対するシミュレーション結果

Fig. 12. Time-domain simulation results for small disturbance.

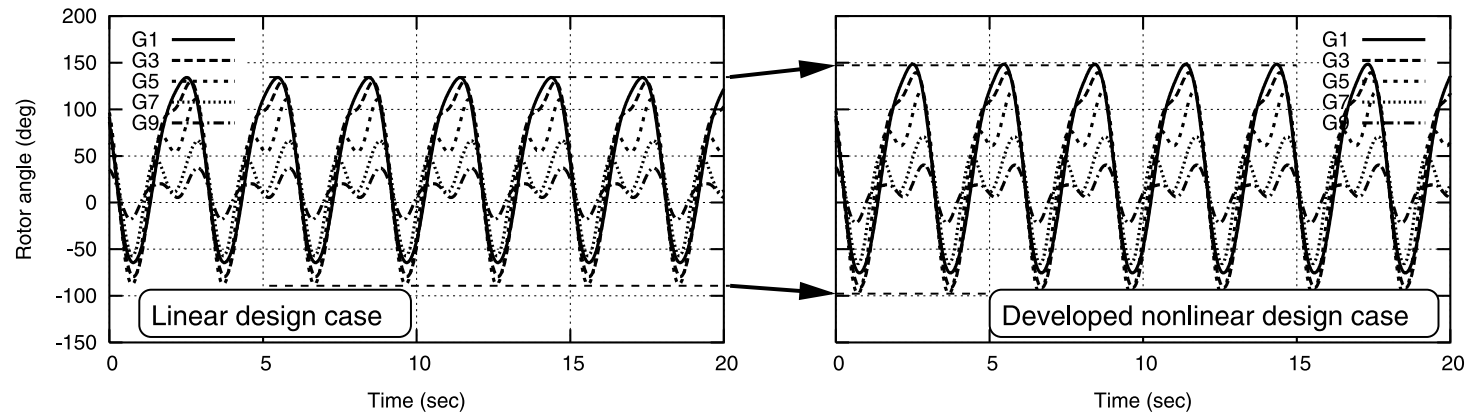

図 13 安定限界となる振幅の変化

Fig. 13. Variation of critical amplitude.

ずつ増加して潮流条件を変更し†，限界送電電力を調べた。 但し，便宜上，位相角基準の発電機 G10 からの位相角の絶 対值が, シミュレーション開始後 30 秒までに 360 度を超 過した場合を不安定と判定し，それ以外は安定と判定する こととした。また，限界送電電力は，前述の判定基準で不 安定と判定されたケースの直前での G1 の発電機出力とす ることとした。その結果,

・固有值を用いて設計した場合：12.35 pu

・開発手法を用いて設計した場合：12.60 pu

となり，限界送電電力は約 $2 \%$ 増加した。

参考として，固有値を用いて設計した場合に最初に不安 定となる G1 の発電機出力 $12.40 \mathrm{pu}$ の潮流条件でのシミュ

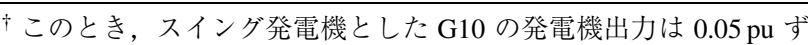
つ減少する。また，正確に言うと，オリジナルの潮流条件（G1 の出 力は $13.50 \mathrm{pu}$ ）では不安定であるため, $\mathrm{G} 1$ 出力は $12.00 \mathrm{pu}$ から徐々 に増加した。
レーション結果を図 14 に示す。

また, WEST10 機系統の G10，およびEAST10 機系統の G10 にPSS を設置した場合に対して，同様に開発手法を適 用して限界送電電力を調べると，それぞれ約 $2 \%$, 約 $8 \%$ の 増加効果が見られた。

〈3・2・6〉 制御系リミッタの影響＼cjkstart制御系リミッタの 影響を見るため, PSS のリミッタを $\pm 0.10 \mathrm{pu}$ から $\pm 0.05 \mathrm{pu}$ に変更して検討を行った。

固有值を用いた設計および開発手法による設計では，制 御系リミッタの影響は考慮できない市ため，設計定数は同 じ值となる。また，小外乱に対しても制御系リミッ夕は影 響しないため同じ結果となる。

安定限界に対応する周期軌道の振幅に関しては, PSS のリ

\footnotetext{
†固有值解析では線形項のみを考慮し, 開発手法では 3 次までの非 線形性のみを考慮するため, 4 次以上の非線形性が影響するリミッ夕 は両者とも考慮できない。
} 

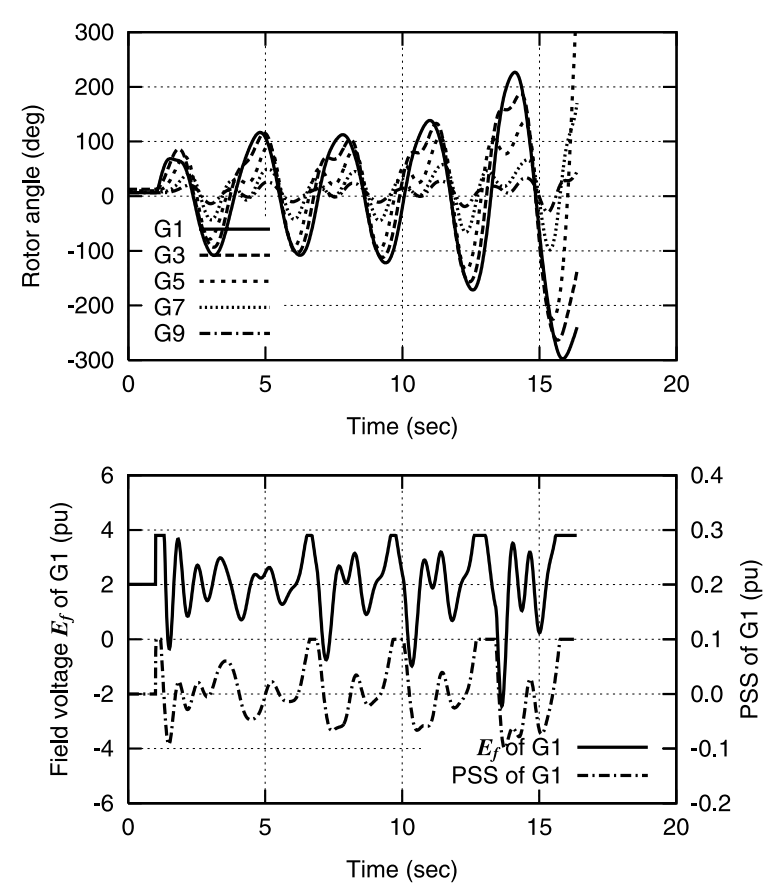

(a) Linear design case
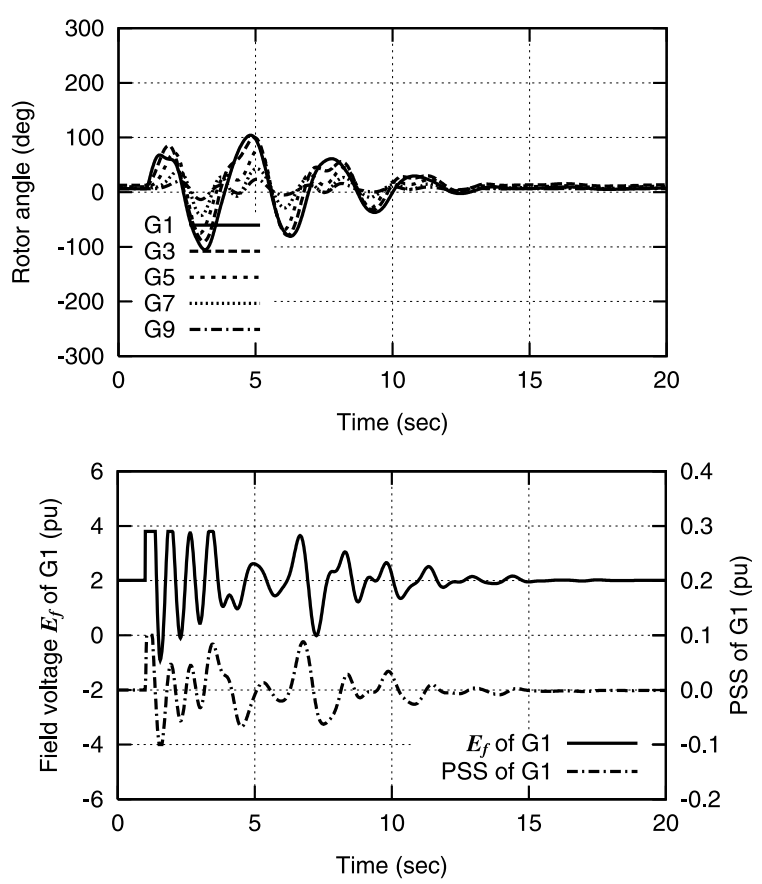

(b) Developed nonlinear design case

図 14 大外乱に対するシミュレーション結果

Fig. 14. Time-domain simulation results for large disturbance.
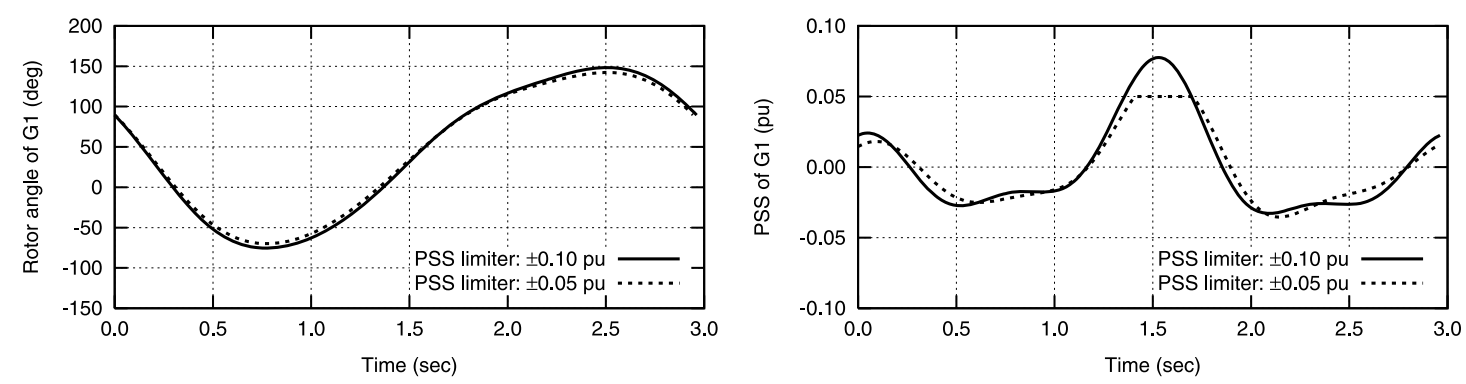

図 15 リミッタが周期軌道に与える影響（開発手法による設計の場合）

Fig. 15. Effect of limiter on periodic orbit in developed nonlinear design.

ミッタの值を変更すると若干小さくなった。開発手法を用 いて設計した場合の周期軌道の変化の様子を図 15 に示す。

また，限界送電電力に関しても

・固有值を用いて設計した場合：12.20 pu

・開発手法を用いて設計した場合： $12.40 \mathrm{pu}$

のように若干小さくなり, 開発手法による増加効果も同様 に隇少した。

したがって，制御系リミッタの影響が大きくなるにつれ て周期軌道の振幅㧍よび限界送電電力は減少し, 開発手法 による増加効果も減少する傾向にあると考えられる。

\section{4. おわりに}

本研究では, 既開発の非線形性を考慮した安定性解析手 法を基に，振動発散の抑制に有効な制御系設計手法を開発 した。また，その有効性の検証のため, 電気学会標準系統モ デルに扔いて開発した手法をPSS の定数設定に適用した。
その結果, 開発手法を用いることにより，小外乱に対する 安定性だけでなく, 非線形性の影響まで考慮した定数設定 を行うことができるため, 線形解析により得られた設計と 比較して限界送電電力の向上が期待できることを示した。 なお，開発した制御系設計手法の適用対象はPSS に限ら ず，従来，固有值解析を用いて安定性の向上が図られてい るSVC などの他の制御系に関しても同様に適用可能と考 えられる。

但し, 既開発の安定性解析手法および今回開発した制御 系設計手法はプロトタイプであり, 実系統への適用には計 算量の面に扔いては課題がある†。今後, 計算の簡略化等に よる計算量の軽減を図ることが必要である。

(平成 18 年 9 月 25 日受付, 平成 19 年 1 月 16 日再受付)

\footnotetext{
†概略, 系の次数の 3 乗に比例して計算量が増大すると考えられる。
} 


\section{文献}

(1) H. Amano, T. Kumano, T. Inoue, and H. Taniguchi: "Proposal of Nonlinear Stability Indices of Power Swing Oscillation in Multi-machine Power System”, IEEJ Trans. PE, Vol.124, No.2, pp.215-221 (2004-2) (in Japanese) 天野博之・熊野照久. 井上俊雄・谷口治人：「多機系統に扔ける非 線形を考慮した動摇安定性指標の提案」, 電学論 B, 124, 2, pp.215-221 (2004-2)

(2) H. Amano, T. Kumano, and T. Inoue: "Application of Nonlinear Stability Indices of Power Swing Oscillation to Analysis of Autoparametric Resonance in Longitudinal Power Systems", IEEJ Trans. PE, Vol.125, No.7, pp.663670 (2005-7) (in Japanese)

天野博之·熊野照久·井上俊雄 :「多機くし形系統における内部共振の 解析への非線形動摇安定性指標の適用」, 電学論 B, 125, 7, pp.663-670 (2005-7)

(3) Y. Kitauchi, H. Taniguchi, T. Shirasaki, Y. Ichikawa, M. Amano, and M. Banjo: "Setting Scheme and Experimental Verification of Multi-Input PSS Parameters for Damping Low Frequency Power Swing in Multi-machine Power System", T. IEE Japan, Vol.122-B, No.1, pp.137-144 (2002-1) (in Japanese)

北内義弘·谷口治人 · 白崎 隆·市川嘉則 · 天野雅彦 · 萬城 実： 「多機系統における長周期動摇抑制用多入力 PSS の定数設定法とそ の実験的検証」, 電学論 B, 122, 1, pp.137-144 (2002-1)

(4) Y. Sudou, A. Takeuchi, M. Kawasaki, Y. Mitani, M. Andou, K. Hirayama, Y. Uemura, N. Fukushima, and T. Sogabe: "Development of a Parallel PSS for Long Term Power Oscillation Damping", T. IEE Japan, Vol.119-B, No.12, pp.1493-1501 (1999-12) (in Japanese)

須藤義也·竹内 昭·川崎 守·三谷嘉伸 ·安藤幹人·平山開一朗· 上村洋一・福島宣夫 ·曽我部敏明：「系統モード抑制用並列型 PSS の開発」, 電学論 B, 119, 12, pp.1493-1501 (1999-12)

(5) K. Yoshimura, N. Uchida, and T. Okada: "Development of Optimizing Method for Generator Excitation System Parameters Considering Overall Stability of Multi-machine Power System", T. IEE Japan, Vol.121-B, No.2, pp.201-209 (2001-2) (in Japanese) 吉村健司 · 内田直之・岡田俊之：「多機系統の安定度を総合的に考 慮した発電機励磁制御系定数最適化手法の開発」, 電学論 B, 121, 2, pp.201-209 (2001-2)

(6) H. Okamoto and Y. Tada: "A Method for Automatic Tuning of PSS under Restriction of Robustness", T. IEE Japan, Vol.119-B, No.12, pp.1502-1509 (1999-12) (in Japanese)

岡本 浩・多田泰之：「ロバスト安定性を考慮したPSS の自動設定 に関する一検討」, 電学論 B, 119, 12, pp.1502-1509 (1999-12)

( 7 ) P. Kunder, M. Klein, G.J. Rogers, and M.S. Zywno: "Application of Power System Stabilizers for Enhancement of Overall System Stability", IEEE Power Syst., Vol.4, No.2, pp.614-626 (1989-5)

（8）電力系統モデル標準化調査専門委員会：「電力系統の標準モデル」, 電 気学会技術報告, No.754 (1999-11)
(9) N. Yorino, Y. Nagashima, T. Kubota, H. Mori, and Y. Tamura: "On Parametric Resonance in Power Systems", T. IEE Japan, Vol.105-B, No.10, pp.805811 (1985-10) (in Japanese)

餘利野直人・長島義明·久保田徹・森 啓之 ·田村康男 : 「電力系 統におけるパラメータ共振について」, 電学論 B, 105, 10, pp.805-811 (1985-10)

(10) N. Kakimoto: "Instability of Low-Frequency Oscillation in Longitudinal Power System due to Autoparametric Resonance", T. IEE Japan, Vol.115, No.3, pp.219-226 (1995-3) (in Japanese)

垣本直人：「長距離くし形系統の内部共振による長周期動摇の不安 定性」, 電学論 B, 115, 3, pp.219-226 (1995-3)

(11) T. Tsuji, R. Hara, and T. Oyama: "A Calculation Method of the Multi Swing Instability Region using Energy Function and Hopf Bifurcation Theory", The Papers of Joint Technical Meeting on PE and PSE, IEE Japan, PE-05-8, PSE-05015 (2005-9) (in Japanese)

辻 隆男・原 亮一・大山 力：「エネルギー関数とホップ分岐理 論を用いた第 $\mathrm{n}$ 波不安定領域算定のための一手法」, 電気学会電力技 術 ·電力系統技術合同研資, PE-05-8, PSE-05-15 (2005-9)

(12) J. Guckenheimer and P. Holmes: Nonlinear Oscillations, Dynamical Systems and Bifurcations of Vector Fields, Springer-Verlag, New York (1983)

(13) S. Wiggins: Introduction to Applied Nonlinear Dynamical Systems and Chaos, Springer-Verlag, New York (1990)

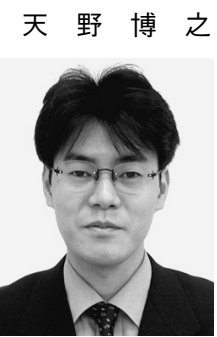

(正員) 1973 年 6 月 8 日生。1996 年 3 月京都大 学工学部電気工学科卒業。1998 年 3 月京都大学 大学院工学研究科電気工学専攻修士課程修了。同 年 4 月（財）電力中央研究所入所，現在に至る。 主に, 電力系統における非線形動特性解析, 周波 数制御に関する研究に従事。2003 年電気学会論 文賞受賞。

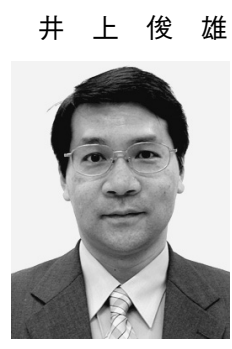

(正員) 1958 年 2 月 15 日生。1982 年 3 月早稲 田大学工学研究科電気工学専攻修士課程修了。同 年 4 月（財）電力中央研究所入所。2006 年 7 月 より電力システム領域リーダー。主として, 需給 制御，電圧 · 無効電力制御に関する研究に従事。 1996，2003 年年電気学会論文賞受賞。1988 年～ 1989 年, 米国テキサス州立大学アーリントン校客 員研究員。IEEE 会員。 